\title{
Difference in the inhibitory effect of black seed extract and the commonly used drug on the intestinal parasites in the primary school students in Mosul and Tikrit cities
}

\author{
Maymona K.Yahya1, Abdul_Rahman A. Altae'2. \\ ${ }^{1}$ Department of clinical laboratory science, College of Pharmacy, University of Mosul, \\ Mosul,Iraq \\ ${ }^{2}$ Department of Microbiology, College of Medicine, University of Aliraqia, Baghdad, Iraq. \\ Email: pharm.maymona@uomosul.edu.iq
}

Received Accepted

1.9.2019 1.12.2019

\section{ABSTRACT}

Objectives: To detect and compare the inhibitory effect of Nigella sativa extracts and compare their effects with traditional drugs on intestinal parasites.

Materials and Methods: Stool samples were collected from 144 students of primary schools: (Al-Arqam primary school for boys, Al-hady primary school for girls, and Al-Arpachia primary school for (boys and girls) in both sexes out of 252 students of about 6-12 years old. Stools were taken from students in a clean water-proof with a tight fitting container $10 \mathrm{ml}$ saline as a transport medium. Each sample was transported at $37^{\circ} \mathrm{C}$ and examined directly under the microscope. They were treated by different doses of different conc. of alcoholic and aqueous extracts of N. sativa and compare the effect with Metronidazole and Albendzole as traditional drugs.

Results: The results of this study revealed clear potentiality of N. sativa as a source for antiparasitic drugs and support its use in folk medicine for the treatment of intestinal infections.

Discussion: There was an inhibitory effect of Nigella sativa on intestinal parasites being isolated but fewer than that of traditional drugs. This finding warrants necessity of further investigation of this product for folk medicine.

Keywords: Nigella sativa extracts, intestinal parasites, Albendazole, Metronidazole 
اختلاف التأثير المثبط لمستخلص الحبة السوداء والدواء الثائع الاستخدام على الطفيليات المعوية لاى الدائ

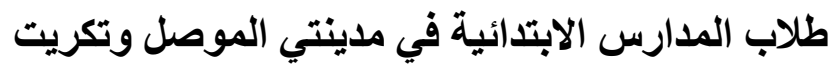

الخلاصة

الهداف البحث: صممت الدراسة للكثف عن التأثير التثبيطي لمستخلصات الحبة السوداء ومقارنتها مع الادوية الثائعة الاستعمال ضد الطفيليات المعوية الو اسعة الانتشار بين تلاميذ المدارس الابتدائية المقدمة:

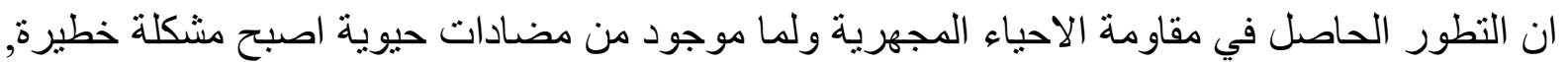

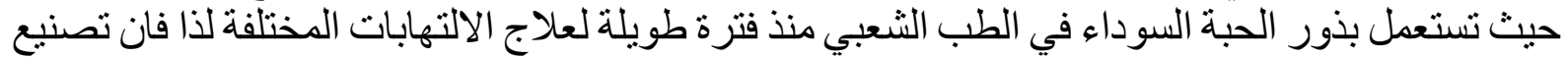

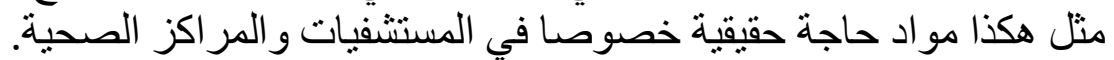

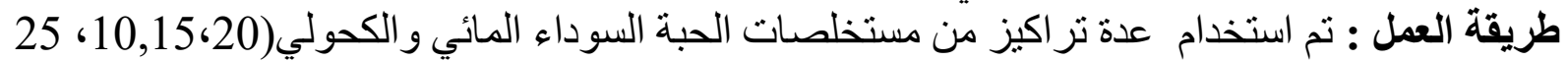

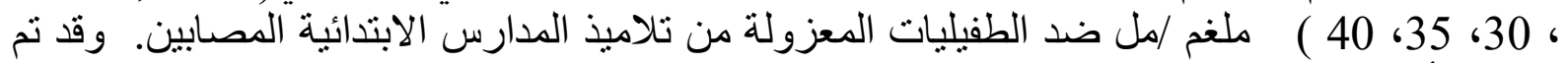
در اسة تأثيره ومقارنتها مع الالبندازول كمضاد حيوي واسع الانتشار يستعمل لعلاج الالتهابات المعوية

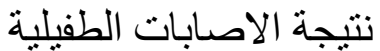
النتائج: بينت لنتائج أن مستخلص الحبة النهابة السوداء له تأثير معنوي في تثبيط الطفيليات المعوية كما اظهرت

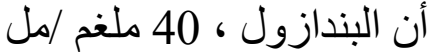

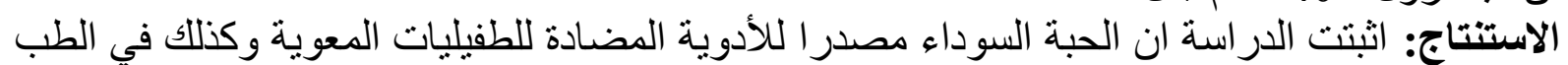

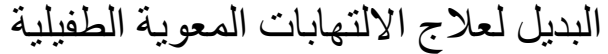
الكلمات المفتاحية: مستخلصات حبة السوداءة، الطية، الطفيليات المعوية ،البندازول ، ميترونيازول.

$\prod \begin{array}{llr}\text { atural } & \text { products } & \text { from } \\ \text { microbial } & \text { and plant } & \text { origin }\end{array}$ have played and still play an important role in drug discovery ${ }^{1}$. Medicinal plants serves as therapeutic alternatives, safer choices, or in some cases, as the only effective treatment. Among the promising medicinal plants, Nigella sativa, a dicotyledonous of the Ranunculaceae family, was an amazing herb with a rich historical and religious background ${ }^{2}$.

The Nigella sativa commonly known as black seed, black cumin or habatul Barakah, is an annual herbaceous plant growing in Mediterranean countries and it is one of the native plants that are widely distributed $^{3}$. Crude extracts (aqueous and alcoholic) of $\mathrm{N}$. sativa were proved to have many therapeutic effects ${ }^{4}$.

Parasitic disease constitutes one of the most serious health problems worldwide today. More than one billion people have been infected by parasites, and many of them are dying from those infections 5. Azoles derivatives e.g. 
Metronidazole and Ketoconazole are the first choice and the most important drugs that used to treat infection with parasite ${ }^{6}$.

The spread of multi-drug resistant pathogens was one of the most serious threats to successful treatment of microbial diseases, Nigella sativa seeds have a great medicinal importance and have been reported to exhibit many pharmacological effects that include anti-parasitic, antibacterial, antifungal, antiviral, antioxidant and anti-inflammatory activities ${ }^{7}$.This research reviews the classical methods commonly used for the evaluation of Nigella sativa aqueous and alcoholic extracts as antiparasitic activities. 
Materials and Methods

\section{Nigella sativa Seed Viability Test}

The seeds were purchased from a local herb shop in Iraq market. There were identified, cleaned to remove any debris, air dried and cultured in a petridishe having wet clean filter paper or gauze and incubated at $(25 \pm 1)^{\circ} \mathrm{C}$ in dark growth chamber for few days. The filter paper were always kept wet by adding enough water to moisten the paper, but pour out any extra water and then calculated the percentage of growth.

Preparation and sterilization of Black Seed Extracts

\section{Alcoholic Extracts}

Nigella sativa alcoholic extract can be prepared depending on Grand route by crushing $20 \mathrm{~g}$ of the seeds(after cleaning it from debris) and dissolve it in $200 \mathrm{ml}$ of $95 \%$ ethanol as in ratio $1: 10(\mathrm{w}: \mathrm{v})$ then put the mixture in refrigerator at $4{ }^{\circ} \mathrm{C}$ for $24 \mathrm{~h}$. The extract were filtered using many layers of gauze then centrifuged at $3000 \mathrm{rpm}$ for $5 \mathrm{~min}$ and the filtrate were filtered through Whitman filter paper no.1. The alcoholic filtrate was evaporated using rotary vacuum evaporator (Rota vapor R11: BUCHI) that evaporate the solvent under low vacuum and under $40{ }^{\circ} \mathrm{C}$ temp to prevent losing the volatile oil which is the main active ingredients present. The filtrate will be further dried by using lyophilizer which dries the filtrate by cooling under low pressure ${ }^{8}$. The alcoholic extracts were kept in refrigerator at $4^{\circ} \mathrm{C}$ until further testing.

For making inhibitory experiments, we should make sterilization for extracts and preparing different concentrations by using crude concentration and that is occur by weight $1 \mathrm{~g}$ of dried alcoholic extract and dissolve it in $5 \mathrm{ml}$ of dissolvent like DEE(diethyl ether). Then sterile the mixture by pasteurization method (heating in the water bath) under $62^{\circ} \mathrm{C}$ for $10 \mathrm{~min}$. 
crude concentration which using for preparing other concentrations ${ }^{9}$.

\section{Aqueous Extract}

Aqueous extracts of Nigella sativa can be prepared depending on Riose route by dissolving $40 \mathrm{~g}$ of seeds (after cleaning it from debris) in $160 \mathrm{ml}$ of sterile distil water in ratio $1: 4(\mathrm{w}: \mathrm{v})$ by using electrical blender inside cool place to prevent losing of volatile oil, for about 1 hour then leaves at $4^{\circ} \mathrm{C}$ for 24 hour (in refrigerator). The extract were filtered by using many layers of gauze and centrifuged at $3000 \mathrm{rpm}$ for $5 \mathrm{~min}$ then filtered by Whitman filter paper no.1. The extract were dried by using lyophilizor that dried by cooling under low vacuum ${ }^{9}$.The dried extract were stored at $4^{\circ} \mathrm{C}$ until using.

Aqueous extracts can be sterile by using Membrane Filter $0.45 \mu$, that is make by dissolving $1 \mathrm{~g}$ of dried aqueous extract in $5 \mathrm{ml}$ of sterile distil water, so we have 200 $\mathrm{mg} / \mathrm{ml}$ extract concentrations as crude concentration, this extracts will be sterilized by filtering through membrane filter $0.45 \mu$ (GEMA MEDICAL S.L. .Spain) to prevent passage of microbe through it and make this concentration as crude, from it we can prepare other concentrations which using in research.

\section{Preparation of Different $N$. sativa} Extracts Concentration

Different concentrations of $N$. sativa (aqueous and alcohol) extracts were prepared starting from $(10,15,20,25,30,35,40) \mathrm{mg} / \mathrm{ml}$ in sterile distil water and diethyl ether as a diluents respectively. Whatmann filter paper No. 1 was used to prepare discs by cutting the paper in a diameter equal to $6 \mathrm{~mm}$. The discs were then sterilized by autoclaving at $121^{\circ} \mathrm{C}$ for $15 \mathrm{~min}$ in tightly closed container having 10 discs. Adding $0.1 \mathrm{ml}$ of different concentrations was prepared to each container and was dried in the bio safety cabinet for 15 minute. Negative control disc were prepared using DEE and DW. 
Positive control disc were prepared using Nytstatin drug ${ }^{10}$.

\section{Intestinal parasites}

\section{Isolation of intestinal parasite}

Stool samples were collected from students of primary schools: (Al-Arqam Primary School for Boys, Al-hady Primary School for Girls, and Al-Arpachia Primary School for Boys and Girls) of about 6-12 years old for the period October 2009November 2010. Stools were taken from students in a clean water-proof with a tight fitting container having transport media $10 \mathrm{ml}$ of normal saline as a transport medium. The container were labelled with patient's full name, age, sex, dates, and time of collection and examined in the laboratory within $24 \mathrm{~h}$ of collection.

Intestinal Parasites were isolated from 252 primary school students being examined. Stool samples were examined by:

\section{Macroscopic Examination}

Noting the colour and consistency of the stool. The presence of small whitish worms in the faeces indicate that the person was infected with Enterobius vermicularis.

\section{Microscopic Examination}

Taking small amount of the stool using clean wooden stick, its prefer on the bloody or mucus part if present, examined microscopically. This is important to see the cyst and larval stage of protozoa and eggs of helminthic. Iodine stain can be used that make the picture more clear by staining the nucleus and the gap that has glycogen ${ }^{11}$.

\section{Scotch tape method}

It consists of a length of Scotch cellulose tape held with adhesiveside-out at the end of a wooden tongue depressor by the thumb and index finger. After swabbing, the tape is removed and placed with the adhesive-side on a glass slide 
Efficacy of Alcoholic and Aqueous

Extract of Nigella sativa on Intestinal Parasites

Students (infected by intestinal Parasites when examined) were treated by different conc. of alcoholic and aqueous extracts of $N$. sativa. The extracts given to the students by capsules in different doses. Compares the effect of $N$. sativa and drug, usually used, occur by further examination of the stool after treatment and note the sign and symptom on the student. Positive control are those students that taking the desired drugs which is Metronidazole in case of protozoa and Albendazole as anthelminthic

\section{Results}

\section{Seed viability test}

Nigella sativa seed were purchased from a local herb shop in Iraq. Three samples were taken with different viability $67 \%, 93 \%$, and $95 \%$, depending on the source of

\section{Preparation of capsules}

Extracts of N. sativa were given to the students by using capsules. Such dosage form were prepared by using empty capsules (purchased from the pharmacy) that were filled with different conc. of the extracts depending on the dose of each students. The dose of each extracts given to the students were calculated as $(0.2,0.5,1) \mathrm{mg}$ of each conc. of the extract $/ \mathrm{kg}$ body weight. The results were mixed with glucose powder to prevent the attachment of the extracts with the wall of the capsule and to make the shape of the capsule in the desired form ${ }^{12}$.

purchasing and storage environment. The favourable one is the highest viability test

\section{Extraction and sterilization of}

\section{Nigella sativa}

As it has mentioned in material and method, N. sativa alcoholic 
extract was in liquid form due to the presence of large amount of oil in the extract and appeared brown in colour. While aqueous extract of $\mathrm{N}$. sativa was in gelatinous form, dark brown in colour, After lyophilisation, it was not converted to powder form due to the presence of oil in the extract that aid to make the extract in high viscous gelatinous form.

\section{Isolation of intestinal parasites}

Intestinal parasite infections are a major health problems ${ }^{13}$. They were isolated from stool of students from four primary schools in Mosul city. Samples were examined macroscopically and microscopically within $24 \mathrm{hrs}$ of collection.

Two hundred fifty two samples were collected from primary schools students. Out of this number, 144 samples were infected with parasites in proportion of about $57.14 \%$. Eighty four samples having single infection in proportion of about $58.33 \%$ and 60 having multiple infection in proportion of about 41.67 $\%$. The percentage of single infection were higher than that of multiple infection in this research as figure (1). 


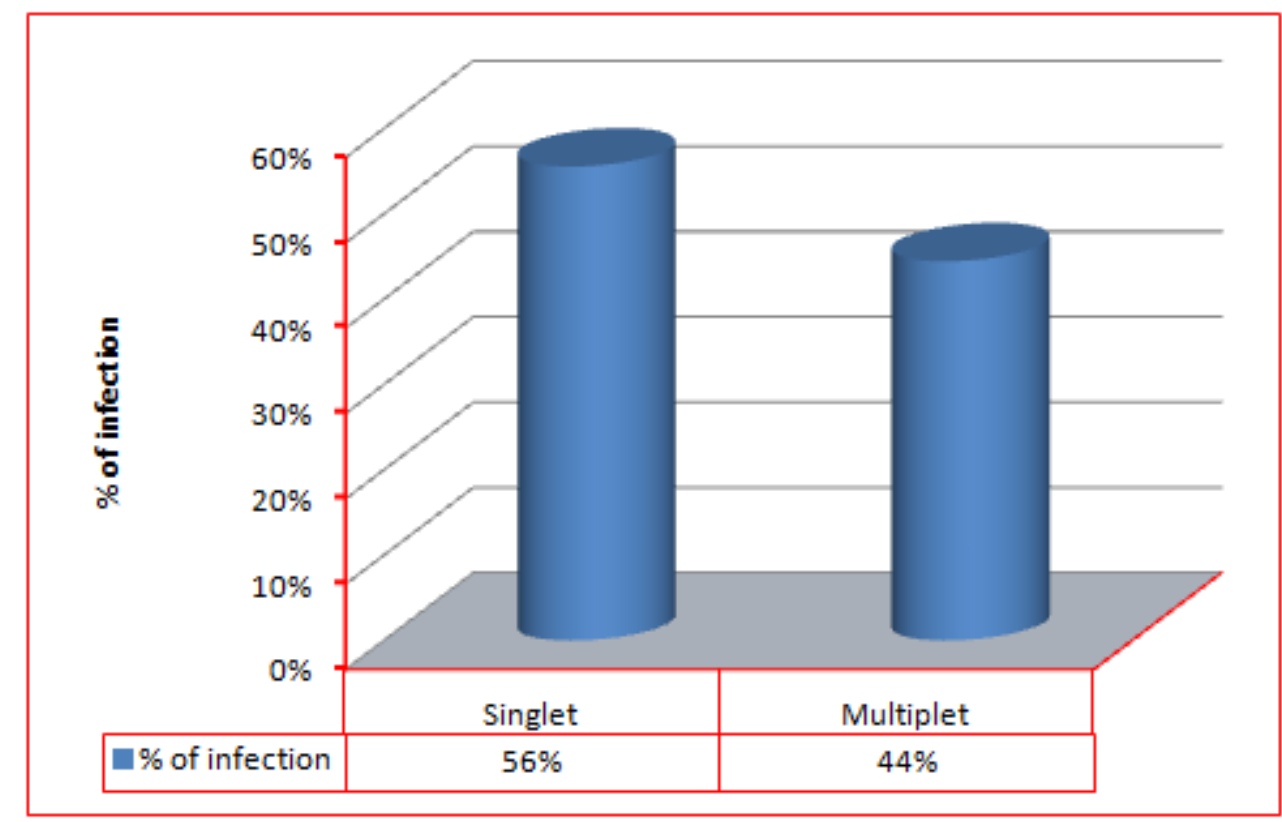

Figure 1. The percentage of infection as single or multiple from infected students.

Protozoa infection was higher than that of helmenthic infection in primary school students. The percentage of protozoa infection was $20.98 \%$ from the infected students (which is represented by Entamoeba histolytica, Entamoeba coli, Giardia lamblia ), while the percentage of helmenthic infection was $12.27 \%$ (which is represented by Enterobius vermicularis ) as in table(1) and figure (2). The percentage of each represent in figure (3). 
Table (1): The percentage of Intestinal Parasite in primary school students

\begin{tabular}{|c|c|c|c|c|}
\hline \multicolumn{2}{|c|}{ Parasites } & $\begin{array}{c}\text { Number } \\
\text { of } \\
\text { infections }\end{array}$ & $\begin{array}{c}\text { \% of infected } \\
\text { Parasites from } \\
\text { other }\end{array}$ & $\begin{array}{c}\text { \% of infection } \\
\text { from the } \\
\text { examined samples }\end{array}$ \\
\hline \multirow{4}{*}{ Protozoa } & $\begin{array}{c}E . \\
\text { histolytica }\end{array}$ & 45 & $23.7 \%$ & $17.9 \%$ \\
\cline { 2 - 5 } & E. coli & 64 & $33.7 \%$ & $25.4 \%$ \\
\cline { 2 - 5 } & G. lamblia & 32 & $16.8 \%$ & $12.7 \%$ \\
\hline \multicolumn{2}{|c|}{ Total Numbers of protozoa } & 141 & $74.2 \%$ & $56.0 \%$ \\
\hline \multirow{2}{*}{ Helimenth } & $\begin{array}{c}\text { E. } \\
\text { virmicularis }\end{array}$ & 49 & $25.8 \%$ & $19.4 \%$ \\
\hline \multicolumn{2}{|c|}{ Overall Numbers } & 190 & $100.0 \%$ & $75.4 \%$ \\
\hline
\end{tabular}

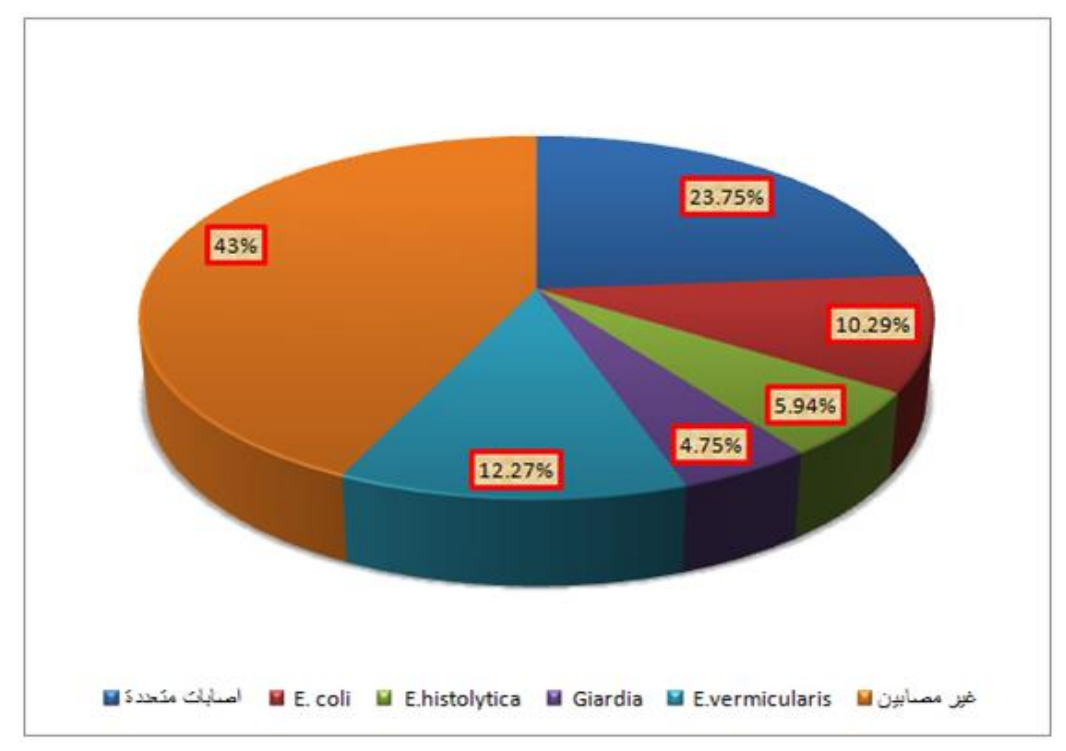

Figure 2: The percentage of infected intestinal parasites between primary school student been examined. 


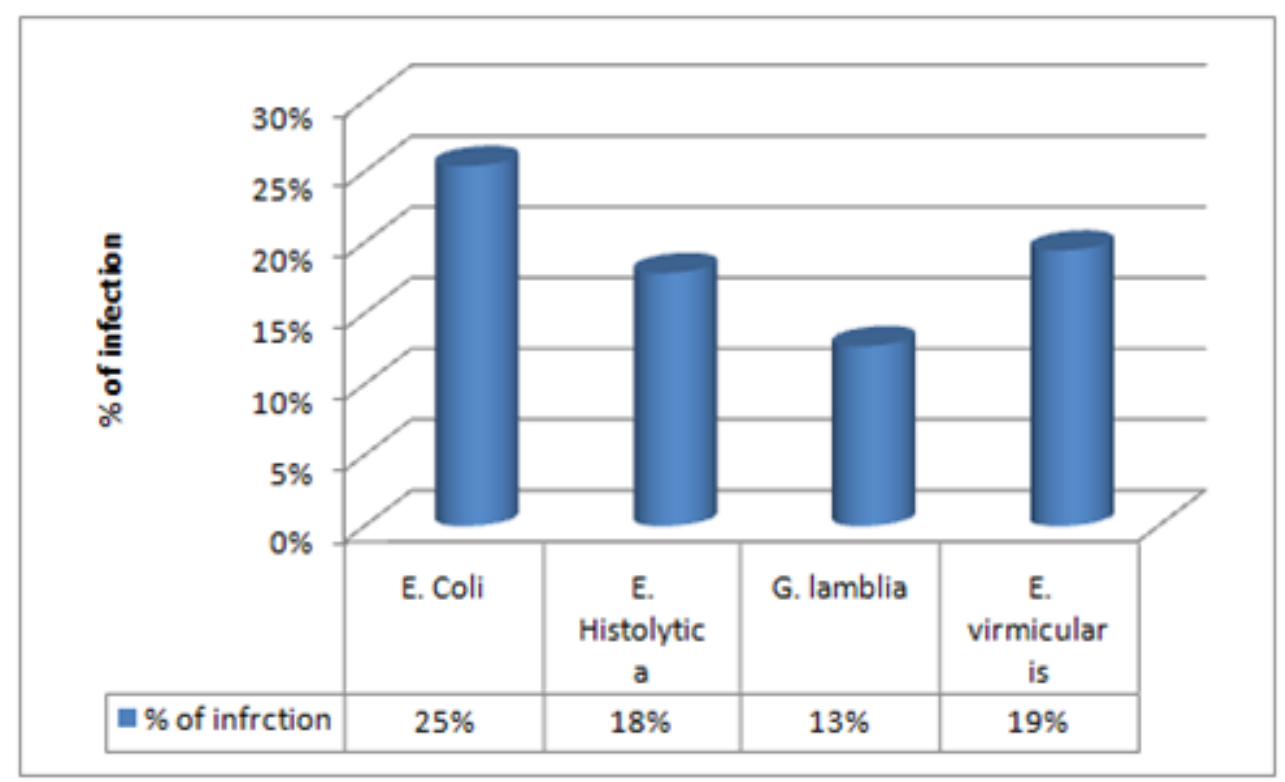

Figure 3. The percentage of intestinal parasitical infection on examined primary school students.

The result also showed that the percentage of infected boys and girls are $18 \%$ and $39 \%$ from examined samples respectively, while $25 \%$ and $18 \%$ are non as in figure (4).

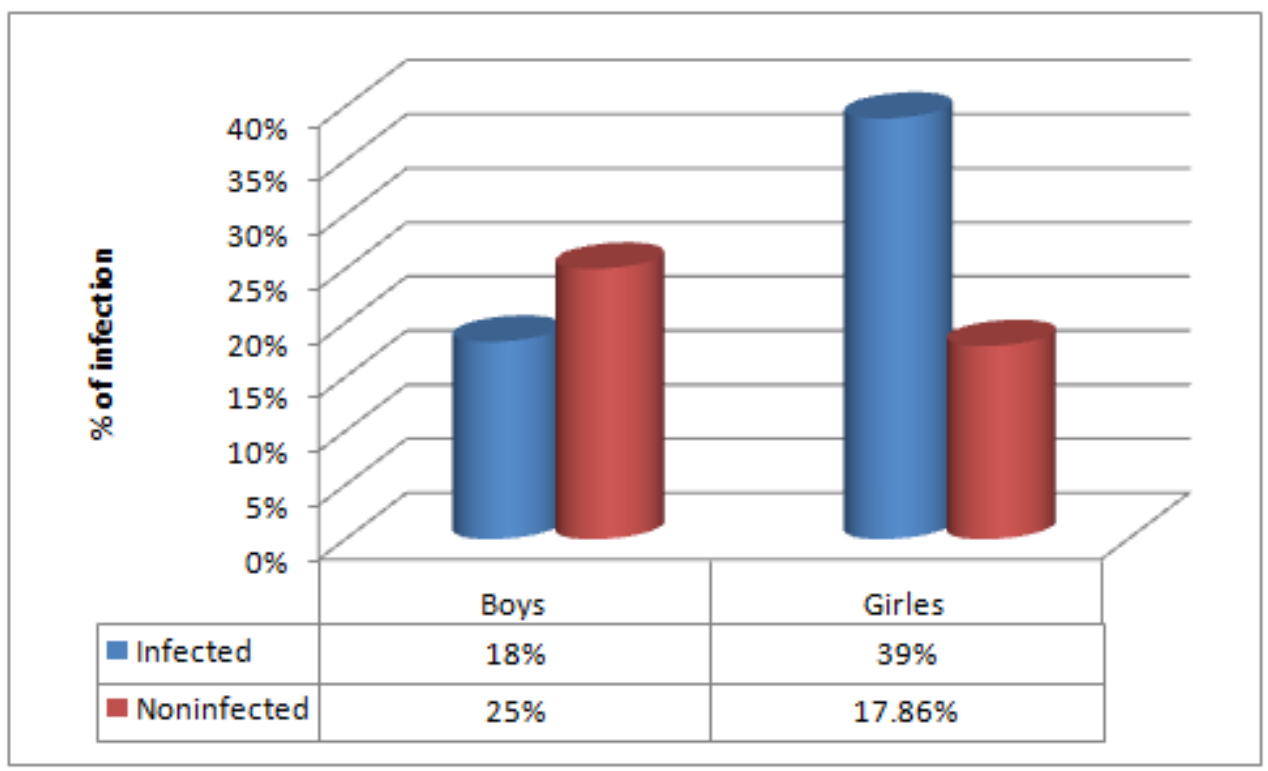

Figure 4. The percentage of intestinal parasitical infection on examined primary school students according to sex. 
However the percentage of infected boys $31.944 \%$ whiles the infected girls are $68.05 \%$.as in table (2) and figure (5).

Table 2: The percentage of Intestinal Parasite in infected primary school students (single infection) according to sex.

\begin{tabular}{|c|c|c|c|}
\hline & \multirow{2}{*}{ Parasites } & \multicolumn{2}{|c|}{ Sex } \\
\hline & & \% Boy & $\%$ Girl \\
\hline \multirow{3}{*}{ Protozoa } & E. histolytica & $4.76 \%$ & $13.09 \%$ \\
\hline & E. coli & $7.14 \%$ & $18.25 \%$ \\
\hline & G. lamblia & $6.35 \%$ & $6.35 \%$ \\
\hline $\begin{array}{c}\text { Total } \\
\text { Numbers }\end{array}$ & & $18.25 \%$ & $37.69 \%$ \\
\hline Helimenth & E. virmicularis & $9.13 \%$ & $10.32 \%$ \\
\hline $\begin{array}{c}\text { Overall } \\
\text { Numbers }\end{array}$ & & $27.38 \%$ & $48.01 \%$ \\
\hline
\end{tabular}

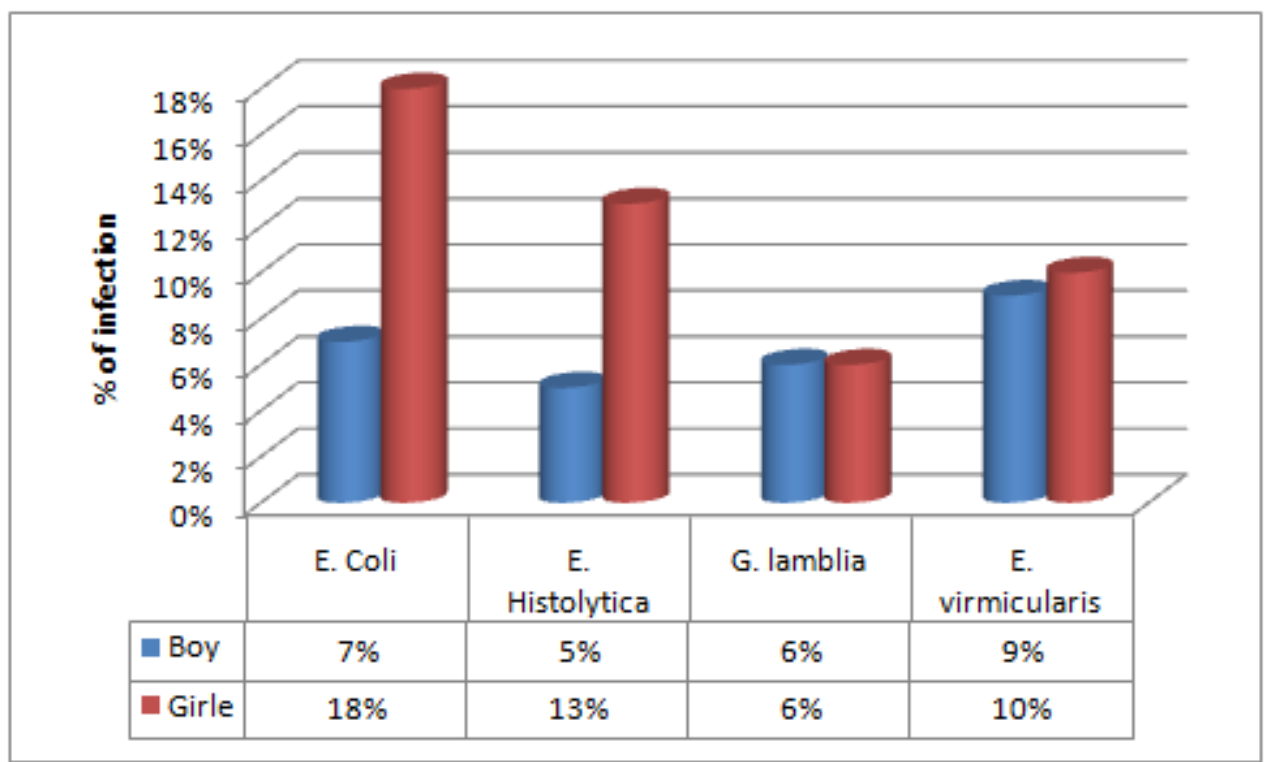

Figure 5. The percentage of intestinal parasitical infection on infected primary school students according to sex. 


\section{Preparation of capsules}

Extracts of N. sativa, either aqueous or alcoholic, were given to the students by using capsules. The dose of the extract were calculated in response to the weight of the students as $(0.2,0.5$, and 1) $\mathrm{mg} / \mathrm{kg}$ body weight. The dose of each extracts given to the students were calculated as $(0.2,0.5,1) \mathrm{mg}$ of each conc. (30 and $40 \mathrm{mg} / \mathrm{ml}$ )of the extract $/ \mathrm{kg}$ body weight. The result were mixed with glucose powder that have beneficial material to the students. When aqueous extract touch the capsule's material, it led to wet it and make it soft within few minutes. On the other side, when alcoholic extract touch the capsule's material, it led to destroy the capsule within seconds.

Efficacy of Alcoholic Extract of Nigella sativa on Intestinal

\section{Parasites}

Infected students were treated by $0.2 \mathrm{mg} / \mathrm{kg}$ of $30 \mathrm{mg} / \mathrm{ml}$ of alcoholic extract didn't have any effect on the infection, while those treated by $0.5 \mathrm{mg} / \mathrm{kg}$ of $30 \mathrm{mg} / \mathrm{ml}$ of alcoholic extract showed that only a few of those having mild infection and low body weight were healed completely (only 5 from 17 infected students). Students taking $1 \mathrm{mg} / \mathrm{kg}$ of $30 \mathrm{mg} / \mathrm{ml}$ of alcoholic extract showed that only 5 from 18 infected students were cured. Students taking $1 \mathrm{mg} / \mathrm{kg}$ of $40 \mathrm{mg} / \mathrm{ml}$ of alcoholic extract showed that only 10 out of 24 infected students were healed, few of them were converted to Candida infection due to unbalance of the intestinal content. When changing the dose giving to the infected students as one capsule for three days, the result were 15 out of 30 infected students and most of protozoa converted to cystic form , but showed many manila and bacterial infection.

Alcoholic extract of N. sativa have effect on the protozoa and helminthic depending on the dose and the percentage of its concentration used. Increasing the dose and concentration of extract used, more favourable results were 13 indicated as in table (3). 
Efficacy of Aqueous Extract of Nigella sativa on Intestinal Parasites

Infected students were treated by $(0.2,0.5$ and 1$) \mathrm{mg} / \mathrm{kg}$ of $30 \mathrm{mg}$ $/ \mathrm{ml}$ of each aqueous extract had no effect on the infection, while those treated by $40 \mathrm{mg} / \mathrm{ml}$ of aqueous extract as one capsule daily in three consecutive days, the result were only 1 case cured completely and $E$. coli converted to cystic form and no effect on E. vermicularis. Increasing the dose to about $3 \mathrm{mg} / \mathrm{kg}$ of $40 \mathrm{mg}$ $/ \mathrm{ml}$ of aqueous extract as one capsule for three days, there was no fungal infection but showed few bacterial infection. Only 1 and 2 cases of $E$. coli and Giardia were cured but had no effect on E. vermicularis as in table (3).

\section{Comparative Efficacy of}

Alcoholic and Aqueous Extract of Nigella sativa and Drugs on

\section{Intestinal Parasites}

The effect of $N$. sativa extracts and drug, usually used, performed by further examination of the stool after treatment and note the sign and symptom on the student. Positive control are those students that taking the desired drugs which was Metronidazole syrup (three times daily for five days) in case of protozoa and Albendazole tablet as anthelminthic (either one tablet before dinner and others before breakfast and/or one tablet before breakfast daily for three successive days) and repeat it after 2 weeks.

The results showed that Metronidazole syrup had good effect on E. coli, E. histolytica and Giardia infections by curing 11, 6 and 4 cases, and the survivor were converted to cystic form. Such results resemble that when $1 \mathrm{mg} / \mathrm{kg}$ of 40 $\mathrm{mg} / \mathrm{ml}$ of aqueous extract as one capsule daily in three successive days used. Albendazole tablet cured 2 out of 6 cases when taken as one tablet before dinner and others before the next breakfast, while healed 10 cases out of 13 when taken as one tablet before breakfast daily for three 
successive days that is better than that showed from extracts of $N$. sativa as in table (3). 
Table 3: Efficacy of Nigella sativa extracts and traditional drugs on intestinal parasites.

\begin{tabular}{|c|c|c|c|c|c|c|c|c|c|c|c|c|}
\hline & \multirow[b]{2}{*}{ Doses used } & \multicolumn{3}{|c|}{ E. coli } & \multicolumn{3}{|c|}{ E. histolytica } & \multicolumn{3}{|c|}{ Giardia } & \multicolumn{2}{|c|}{$\begin{array}{c}\text { E. } \\
\text { vermisularis }\end{array}$} \\
\hline & & $\begin{array}{c}\text { Troph. } \\
+ \\
\text { Cyst }\end{array}$ & $\begin{array}{l}\text { Only } \\
\text { Cyst }\end{array}$ & None & $\begin{array}{r}\text { Troph. } \\
+ \\
\text { Cyst }\end{array}$ & $\begin{array}{l}\text { Only } \\
\text { Cyst }\end{array}$ & None & $\begin{array}{c}\text { Troph. } \\
+ \\
\text { Cyst }\end{array}$ & $\begin{array}{l}\text { Only } \\
\text { Cyst }\end{array}$ & None & Egg & None \\
\hline \multirow{4}{*}{$\begin{array}{c}\text { Alcoholic } \\
\text { extract }\end{array}$} & $\begin{array}{c}0.5 \mathrm{mg} / \mathrm{kg} \text { of } \\
30 \mathrm{mg} / \mathrm{ml}\end{array}$ & 5 & & 5 & 2 & & 1 & 1 & & & 7 & \\
\hline & $\begin{array}{c}1.0 \mathrm{mg} / \mathrm{kg} \text { of } \\
30 \mathrm{mg} / \mathrm{ml}\end{array}$ & 3 & 3 & 3 & 3 & 1 & 3 & & 1 & 3 & 8 & \\
\hline & $\begin{array}{l}1.0 \mathrm{mg} / \mathrm{kg} \text { of } \\
40 \mathrm{mg} / \mathrm{ml} \text { as } \\
\text { one dosage }\end{array}$ & 2 & 7 & 2 & 2 & 3 & 7 & & 2 & 4 & 1 & 1 \\
\hline & $\begin{array}{c}1.0 \mathrm{mg} / \mathrm{kg} \text { of } \\
40 \mathrm{mg} / \mathrm{ml} \text { as } \\
\text { one dosage a } \\
\text { day for three } \\
\text { days }\end{array}$ & & 4 & 5 & & 7 & 3 & & 1 & 3 & 5 & 1 \\
\hline \multirow{2}{*}{$\begin{array}{c}\text { Aqueous } \\
\text { extract }\end{array}$} & $\begin{array}{c}1.0 \mathrm{mg} / \mathrm{kg} \text { of } \\
40 \mathrm{mg} / \mathrm{ml} \text { as } \\
\text { one dosage a } \\
\text { day for three } \\
\text { days }\end{array}$ & 2 & 3 & & 1 & 2 & 1 & & 1 & 2 & 4 & \\
\hline & $\begin{array}{c}3.0 \mathrm{mg} / \mathrm{kg} \text { of } \\
40 \mathrm{mg} / \mathrm{ml} \text { as } \\
\text { one dosage a } \\
\text { day for three } \\
\text { days }\end{array}$ & & 1 & 1 & & 1 & 1 & & 2 & 2 & 8 & \\
\hline \multirow{3}{*}{$\begin{array}{c}\text { Traditional } \\
\text { Drugs }\end{array}$} & Metronidazole & & 2 & 11 & & 1 & 6 & & 1 & 4 & & \\
\hline & Albendazole ${ }^{*}$ & & & & & & & & & & 4 & 2 \\
\hline & Albendazole ${ }^{* *}$ & & & & & & & & & & 3 & 10 \\
\hline
\end{tabular}

* One capsule before dinner and other before breakfast.

**One capsule before breakfast daily for three consecutive days. 


\section{Discussion}

In the present study, investigation was conducted on the activity of Nigella sativa seed extracts, weather alcoholic or aqueous, against Candida albicans isolated from stool samples on primary school students in Mosul and Tikrit city.

Results had been expressed that the percentage of intestinal parasites in primary schools were relatively elevated $57.14 \%$. This percentage agreed the percentage of Rawaa et. Al. ${ }^{14}$ in Bagdad city and Al-Daoody and Rahemo ${ }^{15}$ in Mosul city. The interrelation between this work and the others, due to the resembling of Iraqi circumstances, environmental condition in the presence of difficult economic circumstances, Low sanitary and intellectual awareness of the students and their family and spreading of animal growing habitat inside their houses that available the desired environment for the existing of animals and growing of insects that transfer the cysts and eggs of intestinal parasites. The child played without bearing foot with animals and accumulation of unclean water lead to contaminate their hands and clothes with eggs and cysts of intestinal parasites. Increasing in the percentage of intestinal parasitic infections may be due to their direct life cycle which transferred through air, water, fresh greeneries, disclosed nutrients that met large number of flies which act as a good carrier for eggs of helmenths and cysts of protozoa. This percentage were higher than that represented by $\mathrm{Al}-$ Shirifi HM in Kirkuk city ${ }^{16}$, Jarallah $\mathrm{HM}$ in Basrah city ${ }^{17}$ and Al-Namy, S.H.S. in Mosul city ${ }^{18}$. The percentage were less than that expressed by Al-Taie ${ }^{19}$. This distinctness may be due to the difference of climate and topography of the students, some studies occur in one habitat region, or one social slice. Anyway, the difference in the percentage of parasitic infection was clear in different part of Iraq in different intervals that was difficult to explain the difference. 
The percentage of single infection $58.33 \%$ was higher than that of multiple infection $41.67 \%$. This result were resample that got by Al-Namy, S.H.S. ${ }^{18}$ and Al-Daoody and Rahemo ${ }^{15}$ in Mosul city, Rawaa et. al. hence in the environmental conditions that represent in region, present or absence of intermediate hosts, personal hygiene and immunity degree of the person.

The result also showed that the percentage of infected boys and girls are $18 \%$ and $39 \%$ from examined samples respectively, while $25 \%$ and $18 \%$ are non as in figure ${ }^{17}$. This results were agreed the results of $\mathrm{Al}-$ Taie ${ }^{19}$ in Baghdad city that showed infected girls were higher than boys. The results were disagreed AL-Qadhi et. al. ${ }^{20}$, in Baghdad, Kadi and Amin ${ }^{21}$ in Sulaimania, Jarallah HM ${ }^{17}$ in Basra, Al-Daoody and Rahemo ${ }^{15}$ in Nineveh.

N. sativa extracts were proved to have an immunmodulatory effect. N. sativa has a prominent stimulatory effect on CD4 positive T-cells and macrophages causing an immunomodulatory effect both in humans and animals. However, their exact mechanism of action on the individual components of the immune system needs to be deeply investigated. Understanding of such mechanisms will put a great impact on the management of many infectious as well as immunological disorders ${ }^{22}$.

The inhibitory effect of the extracts were depend on the severity of infection, immunity, age, low sanitary and intellectual awareness of the students and their family, dose, concentration and rout of administration of the extracts ${ }^{23 \& 24}$.

\section{Acknowledgment}

The authors are very grateful to the University of Mosul/ College of pharmacy for their provided facilities , which helped to improve the quality of this work. 


\section{References}

1. Akshada AK, Rajendra CDand Chandrakant SM. Pharmacognosy - Medicinal Plants. Natural products in drug discovery. Licensee. Intech Open.2019; 1-19. DOI: 10.5772/intechopen.82860

2. Yahya MQ. Variations in the viability and macromolecules concentration of E. granulosus protoscolices isolated from ruminants consequence treatment with Nigella sativa seed's oil (In vitro study). Iraqi J. Vet. Sci. 2019; 33(2): 2019 (227-234).

doi:

\section{$\underline{10.33899 / \mathrm{ijvs.2019.162880}}$}

3. Mohammad, M. A., Mohammad, M. M. J., and Dradka, H. Effect of Black Seed (Nigella sativa) on Spermatogenesis and Fertility of Male Albino Rats. Research Journal of Medicinal Sciences, 2009; 4(2): 386-390.

4. Heba

AbdelKader

Aminou, Yosra Hussein
Alam-Eldin, and Hanan

Ahmed Hashem. Effect of Nigella sativa alcoholic extract and oil, as well as Pharsalus vulgaris (kidney bean) lectin on the ultrastructure of Trichomonas vaginalis trophozoites. $\quad \underline{J}$ Parasit Dis. 2016; 40(3): 707713.

5. Rashidul Haque Human Intestinal Parasites. $\mathrm{J}$ Health Popul Nutr. 2007; 25(4): 387391.

6. Muhannad F AlKobaisi*.Jawetz, Melnick \& Adelberg's Medical Microbiology 24th Edition. Sultan Qaboos Univ Med J. 2007; 7(3): 273-275.

7. Abu-Al-Basal, M. A., In vitro and In vivo Anti-microbial effects of Nigella sativa Linn. seed extracts against clinical isolates from skin wound infections. Am. J.of Appl. Sci. , 2009; 6 (8): 1440-1447.

8. Grand, A., Woudergem, P. A., Verpoortes, R., and Pousset, J. 
L., Anti infections

phytotherapies of Tree savannah of Senegal (West Africa), II Antimicrobial activity of 33 species. Journal Ethnopharmacol. 1988; 22: 25-31.

9. Riose, J. L., Recio, M. C. and Villar, A., Antimicrobial activity of selected plant employed in the Spanish Mediterranean area. Journal Ethnopharmacology, 1987;21:139-152.

10.Hannan, A., Saleem, S., Chaudhary, S., Barkaat, M., M. U. Antibacterial Activity of Nigella sativa Against Clinical Isolates of Methicillin Resistant Staphylococcus aureus. Journal Ayub Med. Coll. Abbottabad, 2008;20(3)

11.Hafsa Afroz, G.M. Raisul Alam, Md. Manjur Hossain, Md. Fakruddin, Md. Hafizur Rahman, Zahed Uddin Mahmood Khan, Suvamoy Datta. Evaluation of IodineGlycerol for Wet-Mount
Preparation of Faces for Detection of Intestinal Parasites. Int J Biol Med Res. 2013; 4(4): 3615-3618.

12.Tianquan Lin, , Yufeng Tang, Yaoming Wang, Hui Bi， Zhanqiang Liu, Fuqiang Huang, Xiaoming Xie, and Mianheng Jiang . Scotch-tapelike exfoliation of graphite assisted with elemental sulphur and grapheme/sulphur composites for highperformance lithium-sulphur batteries. The Royal Society of Chemistry 2013: 1-9.

13.Tai-Soon, Y., Seobo, S., Jongweon, L., Heechoul, O., Myung-Ho, K., and Hyunsoo, K., A small-scale survey on the status of intestinal parasite infections in rural villages in Nepal. The Korean J. of Parasitology 2000; 38(4): 275277.

14.Rawaa A. h.,Mohammed J.K. and Hadeel A.M. Prevalence of intestinal parasitic infections among children in 
Baghdad city. nt $\mathrm{J}$ Infect Microbiol 2013; 2(3): 111113 DOI:

10.3126/ijim.v2i3.8205

15. Ahmed Akil Khudhair AlDaoody, Zohair I.F. Rahemo. Prevalence of Intestinal Helminths Infection among Pupils of a Number of Primary School in Nineveh Governorate. Rafidain Journal of Science. 2003;14(2): 32-40.

16.Al-Shirifi HM. Prevalence of intestinal parasites among pupils of primary schools and foodhandlers in ALTaamem province, Iraq. M. Sc. Thesis, Mosul University.2000:pp. 180.

17.Hind Mahdi Jarallah. Intestinal parasitic infections among rural villages in Basrah marshes regions. Journal of Basrah Researches Sciences. 2012;38(2):40-43.

18.Al-Naemy,S. H. S., An epidemiological study of diarrhea causing parasites in Nineveh governorate and estimation of immunoglobulines level and serum albumin in patients infected with some intestinal parasites. M. Sc. Thesis. Mosul University. 2001:4656.

19.Lazem H. K. Al-Taie. Prevalence of Intestinal Parasitic Infection in Baghdad City. Fac Med Baghdad 2009;51(2): 187-191.

20.Ban N. AL-Qadhi, Harith S.J. AL-Warid,* Menahel N. ALQadhi . enterobiasis and its relationship with enuresis among one of orphanage care children in Baghdad- Iraq . Iraqi journal of science,2011; $.52(3): 394-399$

21.Mohammad Abdul Aziz Kadi and Omer Mahmud Amin. Prevalence of enterobiasis (Enterobius vermicularis) and its impacts on children in Kalar town/ Sulaimania-Iraq. Tikrit Medical Journal 2011; 17(2): 67-77 
22.Abdulkader M.D. Tonkal. In Vitro Anti trichomonal effect of Nigella Sativa aqueous extract and wheat germ agglutinin. JKAU: Med. Sci. 2009;16(2): 17-34. DOI: 10.4197/Med. 16-2.2

23. Maymona K.Yahya*; Abdul_Rahman A. Altae. Comparative evaluation of the effect of Nigella sativa extracts and nystatin as a traditional drug on Candida albicans in the primary school students in Mosul and Tikrit cities. Iraq $\mathrm{J}$ Pharm.2013;13(2):70-78.

24.Heny Ekowati1, ${ }^{*}$ Eka Prasasti1, and Undri Rastuti. The active fraction from Nigella sativa and its activity against T47D cell line. Indo. J. Chem. 2011;11(3): 217 - 222 